\title{
Pengaruh Pemberian Pupuk Npk Mutiara Terhadap Pertumbuhan Bibit Jati Belanda (Guazuma Ulmifolia Lamk) Pada Tanah Podsolik Merah Kuning
}

\author{
M. Kurniawan Candra, S. Hut, MP. 1), Indra Candra Nababan 2) \\ 1). Staf Pengajar Prodi Kehutanan 2) Mahasiswa Prodi Kehutanan \\ Fakultas Pertanian Universitas Kapuas Sintang \\ Email : candra.kurniawanmuhammad@gmail.com
}

\begin{abstract}
Abstrak: Penelitian ini bertujuan untuk mengetahui pengaruh pemberian pupuk NPK Mutiara dan dosis yang terbaik dalam mempengaruhi pertumbuhan bibit Jati Belanda pada tanah Podsolik Merah Kuning.

Metode yang digunakan dalam penelitian ini adalah adalah Rancangan Acak Lengkap (RAL) dengan perlakuan tunggal dosis pupuk NPK Mutiara yang terdiri dari 6 taraf perlakuan yaitu : Tanpa pupuk NPK Mutiara (N0), NPK Mutiara 3 gram per tanaman (N1), NPK Mutiara 4 gram per tanaman (N2), NPK Mutiara 5 gram per tanaman (N3) dan NPK Mutiara 6 gram per tanaman (N4) dan NPK Mutiara 7 gram per tanaman (N5). Rancangan ini dipilih karena bibit Jati Belanda dan alat penelitian yang digunakan seragam/homogen.

Hasil penelitian diketahui bahwa Pemberian pupuk NPK Mutiara berpengaruh sangat signifikan terhadap pertambahan jumlah daun dan pertambahan tinggi bibit Jati Belanda pada tanah Podsolik Merah Kuning. Perlakuan pemberian pupuk NPK Mutiara dengan dosis 6 gram per bibit (N4) dan 7 gram per bibit (N5) adalah yang terbaik dibandingkan dengan perlakuan lainnya, yang mampu memacu rerata pertambahan jumlah daun sebanyak 16,75 (helai) dan rerata pertambahan tinggi bibit Jati Belanda sebanyak $33,50 \mathrm{~cm}$.
\end{abstract}

Kata Kunci : Pupuk NPK Mutiara, Pertumbuhan Tinggi dan Jumlah Daun, Bibit Jati Belanda dan Tanah Podsolik Merah Kuning

\section{PENDAHULUAN}

\section{Latar Belakang}

Tanaman Jati cukup dikenal oleh masyarakat Indonesia, terutama yang dapat menghasilkan kayu. Di Indonesia, sesungguhnya terdapat tiga jenis Jati, yaitu Jati Belanda (Guazuma ulmifolia Lamk), Jati (Tectona grandis L) dan Jati Awang (Hymenodictyron excelsum Wall). Tanaman Jati Belanda secara umum dimanfaatkan untuk keperluan pengobatan berbagai macam penyakit. Hampir semua bagian tanaman ini dapat dipergunakan untuk pengobatan. Daun, buah, biji, dan kulit kayu bagian dalam merupakan bagian tanaman yang bisa dipergunakan sebagai obat. Secara umum, zat utama yang terkandung dari seluruh bagian tanaman adalah tanin dan musilago. Kandungan lainnya yaitu resin, flavonoid, karotenoid, asam fenolat, zat pahit, karbohidrat, kafein, 
Pengaruh Pemberian Pupuk Npk Mutiara Terhadap Pertumbuhan Bibit Jati Belanda (Guazuma Ulmifolia Lamk) Pada Tanah Podsolik Merah Kuning

terpen, juga senyawa - senyawa lain seperti sterol, beta-sitosterol, friedelin3-alfa-asetat, friedelin -3-betaol,alkoloida serta karbohidrat dan minyak lemak. Hal ini yang menjadi alasan banyaknya daun jati belanda yang dimanfaatkan sebagai obat susut perut dan pelangsing. Dalam perkembangannya, daun Jati Belanda juga banyak dimanfaatkan untuk mengatasi penyakit kolesterol dan rematik gout. Tak hanya sampai di situ, dewasa ini daun jati Belanda juga dapat digunakan sebagai obat elephantiasis atau penyakit kaki gajah.

Upaya budi daya bibit Jati Belanda sebagai langkah awal dapat dilakukan dengan menggunakan bibit yang tersedia dan dilakukan perlakuan tertentu. Untuk mendapatkan bibit yang berkualitas, diperlukan media tumbuh yang sesuai dan pemberian pupuk tertentu yang salah satunya dapat menggunakan pupuk NPK Mutiara.

Oleh karena itu, perlu dilakukan kajian mengenai penggunaan pupuk NPK Mutiara dalam proses pembibitan untuk tumbuh dan berkembangnya bibit Jati Belanda.

\section{METODOLOGI PENELITIAN}

\section{Rancangan Penelitian}

Rancangan yang digunakan dalam penelitian ini adalah Rancangan Acak Lengkap (RAL) dengan perlakuan tunggal dosis pupuk NPK Mutiara yang terdiri dari 6 taraf perlakuan yaitu : Tanpa pupuk NPK Mutiara (N0), NPK Mutiara 3 gram per tanaman (N1), NPK Mutiara 4 gram per tanaman (N2), NPK Mutiara 5 gram per tanaman (N3) dan NPK Mutiara 6 gram per tanaman (N4) dan NPK Mutiara 7 gram per tanaman (N5). Rancangan ini dipilih karena bibit Jati Belanda dan alat penelitian yang digunakan seragam/homogen.

Jumlah populasi dalam penelitian ini adalah 6 taraf perlakuan dosis pupuk NPK Mutiara, masing-masing perlakuan diulang sebanyak 4 kali dan setiap ulangan terdapat 4 bibit, sehingga terdapat 96 bibit Jati Belanda. Sampel dalam penelitian ini, yaitu setiap ulangan diambil sebanyak 2 bibit sehingga bibit Jati Belanda yang diamati sebanyak $6 \times 4$ ulangan $\times 2$ bibit $=48$ bibit.

Bahan yang digunakan dalam penelitian ini adalah :

1. Bibit Jati Belanda dengan tinggi, diameter dan jumlah daun yang 
seragam/homogen digunakan

sebagai objek penelitian;

2. Pupuk NPK Mutiara, digunakan sebagai perlakuan dengan dosis yang telah ditentukan (NPK Mutiara 3 gram per tanaman, NPK Mutiara 4 gram per tanaman, NPK Mutiara 5 gram per tanaman, NPK Mutiara 6 gram per tanaman dan NPK Mutiara 7 gram per tanaman);

3. Tanah PMK, digunakan sebagai media tanam bibit Jati Belanda;

4. Air, digunakan untuk menyiram bibit Jati Belanda selama penelitian;

5. Polybag ukuran $15 \times 15 \times 25 \mathrm{~cm}$, digunakan untuk menanam bibit Jati Belanda;

6. Paranet dengan intensitas $50 \%$ dan atau daun alang-alang, digunakan sebagai atap naungan pembibitan.

7. Fungisida, digunakan untuk mencegah jamur yang tumbuh pada bibit Jati Belanda.

Adapun alat-alat yang digunakan dalam penelitian ini adalah :

1. Parang, sabit dan cangkul, digunakan untuk membuka lahan dan menyiapkan persemaian

2. Handsprai, digunakan untuk keseragaman penyiraman;

3. Kamera, digunakan untuk dokumentasi penelitian;
4. Alat tulis/buku, digunakan untuk mencatat semua kegiatan penelitian;

5. Mistar ukur/Meteran, digunakan untuk mengukur tinggi tanaman;

6. Timbangan analitik, untuk menimbang pupuk NPK Mutiara;

7. Kayu dan papan, untuk membuat papan nama perlakuan pada petak percobaan.

\section{Pelaksanaan Penelitian}

1. Pembuatan Naungan

Naungan dibuat dengan menggunakan paranet dengan intensitas $50 \%$. Adanya naungan dimaksudkan untuk menghindari sinar matahari dan hujan secara langsung. Naungan dibuat dengan tinggi sebelah timur $2,5 \mathrm{~m}$, sebelah barat 2 meter dan panjang 3,5 m sedangkan lebarnya $2,5 \mathrm{~m}$.

\section{Penyiapan Media Tanam}

Persiapan media tanam sebagai tempat pertumbuhan bibit Jati Belanda dilakukan dengan cara tanah dihancurkan atau digemburkan. Media tanam yang akan digunakan berupa tanah pada lokasi penelitian dicangkul dan dikering anginkan lebih kurang selama 1 minggu. Selanjutnya tanah sebagai media tanam yang telah kering 
angin tersebut digemburkan sampai benar - benar merata, kemudian dimasukkan kedalam polybag sesuai dengan ukuran / takaran yang telah ditentukan (2/3 bagian dari polybag yang digunakan).

\section{Penyemaian Benih Jati Belanda}

Benih Jati Belanda disemai langsung pada media dalam polybag yang telah disiapkan. Penyemaian dilakukan dengan cara membenamkan benih/biji sedalam $1 \mathrm{~cm}$ pada media dalam polybag, kemudian ditutup tipis dengan media semai dan disiram dengan mengunakan handsprai. Setiap polybag disemai sebanyak 2 benih/biji Jati Belanda.

\section{Pemilihan Bibit Jati Belanda}

Bibit Jati Belanda yang digunakan dalam penelitian ini adalah bibit hasil persemaian. Setiap polybag bibit yang digunakan hanya 1 (satu) dipilih bibit yang terbaik dengan kriteria jumlah daun, tinggi dan diameter batang yang sama/seragam. Bibit yang digunakan dalam penelitian adalah yang mempunyai 3 daun dengan tinggi dan lingkar batang yang sama.
5. Penyiapan Pupuk NPK Mutiara dan Perlakuan

Pupuk NPK Mutiara ditimbang dan ditaburkan kedalam larikan pada polybag dengan dosis NPK Mutiara 3 gram per tanaman (N1), NPK Mutiara 4 gram per tanaman (N2), NPK Mutiara 5 gram per tanaman (N3) dan NPK Mutiara 6 gram per tanaman (N4) dan NPK Mutiara 7 gram per tanaman (N5). Pemupukan dilakukan pada pagi hari sekitar pukul 07.00 WIB dan diberikan sekali selama penelitian yaitu 2 minggu setelah benih/Jati Belanda tumbuh.

\section{Pemeliharaan}

Pemeliharaan dilakukan meliputi pencabutan semua jenis gulma yang terdapat pada media sekitar bibit Jati Belanda, serta dilakukan penyiraman secara rutin setiap pagi dan sore hari kecuali jika terjadi hujan, maka tidak dilakukan penyiraman.

\section{Pengamatan dan Pengumpulan Data}

Pengamatan dan pengumpulan data penelitian meliputi :

1. Pertambahan Jumlah Daun (Helai)

2. Pertambahan Tinggi Tanaman $(\mathrm{cm})$ 


\section{Analisis Data}

Data hasil penelitian dianalisis sesuai dengan rancangan penelitian yang digunakan. Menurut Hanafiah (2008:25), model statistika untuk percobaan tunggal dengan menggunakan rancangan dasar RAL, adalah sebagai berikut:

$\mathbf{Y}_{\mathbf{i j}}=\mu+\tau \mathbf{i}+\varepsilon \mathbf{i j}$

\section{HASIL DAN PEMBAHASAN}

\section{Hasil Penelitian}

\section{Pertambahan Jumlah Daun Bibit Jati}

\section{Belanda}

Pertambahan jumlah daun bibit Jati Belanda merupakan hasil perhitungan, yang didapatkan dengan cara mengurangi jumlah daun bibit pada akhir penelitian dengan jumlah daun bibit pada awal penelitian.

Tabel .1. Data Rerata Pertambahan Jumlah Daun Bibit Jati Belanda Pada Tanah Podsolik Merah Kuning

\begin{tabular}{|c|c|c|c|c|c|c|}
\hline \multirow{2}{*}{ Perlakuan } & \multicolumn{4}{|c|}{ Ulangan } & \multirow{2}{*}{ Jumlah } & \multirow{2}{*}{ Rerata } \\
\hline & 1 & 2 & 3 & 4 & & \\
\hline No & 7 & 9 & 8 & 8 & 32,00 & 8,00 \\
\hline N1 & 12 & 12 & 13 & 12 & 49,00 & 12,25 \\
\hline $\mathbf{N 2}$ & 14 & 15 & 15 & 15 & 59,00 & 14,75 \\
\hline N3 & 15 & 15 & 15 & 16 & 61,00 & 15,25 \\
\hline N4 & 17 & 15 & 18 & 17 & 67,00 & 16,75 \\
\hline N5 & 15 & 17 & 18 & 17 & 67,00 & 16,75 \\
\hline Jumlah & 80,00 & 83,00 & 87,00 & 85,00 & 335,00 & 83,75 \\
\hline
\end{tabular}

Sumber : Data Hasil Penelitian

Berdasarkan hasil analisis sidik ragam diketahui bahwa pemberian pupuk NPK Mutiara memberikan pengaruh yang sangat signifikan terhadap pertambahan jumlah daun bibit Jati Belanda pada tanah Podsolik Merah Kuning. 
Tabel 2. Uji Beda Nyata Terkecil Pengaruh Pemberian Pupuk NPK Mutiara Terhadap Pertambahan Jumlah Daun Bibit Jati Belanda Pada Tanah Podsolik Merah Kuning

\begin{tabular}{|c|c|c|c|c|c|c|c|}
\hline \multirow{2}{*}{ Perlakuan } & \multirow{2}{*}{ Rerata } & \multicolumn{6}{|c|}{ Beda } \\
\hline & & No & N1 & N2 & N3 & N4 & N5 \\
\hline No & 8,00 & & & & & & \\
\hline N1 & 12,25 & $4,25^{* *}$ & & & & & \\
\hline N2 & 14,75 & $6,75^{* *}$ & $2,50 * *$ & & & & \\
\hline N3 & 15,25 & $7,25 * *$ & $3,00 * *$ & $0,50^{\mathrm{ns}}$ & & & \\
\hline N4 & 16,75 & $8,75^{* *}$ & $4,50 * *$ & $2,00 * *$ & $1,50 * *$ & & \\
\hline N5 & 16,75 & $8,75^{* *}$ & $4,50 * *$ & $2,00 * *$ & $1,50 * *$ & $0,00^{\mathrm{ns}}$ & \\
\hline
\end{tabular}

Sumber : Analisis Data Penelitian, 2017.

Keterangan : $* *=$ Berbeda sangat signifikan

$\mathrm{ns}=$ Tidak berbeda signifikan

Hasil uji BNT diketahui bahwa pemberian pupuk NPK Mutiara dengan dosis 6 gram per bibit (N4) dan 7 gram per bibit Jati Belanda (N5), merupakan perlakuan terbaik untuk meningkatkan pertambahan jumlah daun bibit Jati Belanda. Hal ini terlihat dengan jelas bahwa N5 dan N4 tidak berbeda (menghasilkan pertambahan jumlah daun yang sama), dan kedua perlakuan tersebut berbeda sangat signifikan dibandingkan dengan perlakuan lain N3 (pupuk NPK Mutiara
5 gram per bibit), dengan N2 (pupuk NPK Mutiara 4 gram per bibit), N1(pupuk NPK Mutiara 3 gram per bibit) dan dengan NO (tanpa pupuk NPK Mutiara).

\section{Pertambahan Tinggi Bibit Jati Belanda}

Pertambahan tinggi bibit merupakan hasil perhitungan yang didapat dengan cara mengurangi tinggi bibit pada akhir penelitian dengan tinggi bibit pada awal penelitian. 
Pengaruh Pemberian Pupuk Npk Mutiara Terhadap Pertumbuhan Bibit Jati

Belanda (Guazuma Ulmifolia Lamk) Pada Tanah Podsolik Merah Kuning

Tabel 3. Data Rerata Pertambahan Tinggi Bibit Jati Belanda Pada Tanah Podsolik Merah Kuning

\begin{tabular}{|c|c|c|c|c|c|c|}
\hline \multirow{2}{*}{ Perlakuan } & \multicolumn{4}{|c|}{ Ulangan } & \multirow{2}{*}{ Jumlah } & \multirow{2}{*}{ Rerata } \\
\hline & 1 & 2 & 3 & 4 & & \\
\hline No & 25 & 24 & 25 & 25 & 99,00 & 24,75 \\
\hline N1 & 30 & 31 & 31 & 31 & 123,00 & 30,75 \\
\hline N2 & 31 & 33 & 32 & 31 & 127,00 & 31,75 \\
\hline N3 & 33 & 32 & 31 & 33 & 129,00 & 32,25 \\
\hline N4 & 34 & 33 & 34 & 33 & 134,00 & 33,50 \\
\hline N5 & 33 & 33 & 34 & 34 & 134,00 & 33,50 \\
\hline Jumlah & 186,00 & 186,00 & 187,00 & 187,00 & 746,00 & 186,50 \\
\hline
\end{tabular}

Sumber : Data Hasil Penelitian

Berdasarkan hasil analisis sidik ragam diketahui bahwa pemberian pupuk NPK Mutiara memberikan pengaruh yang sangat signifikan terhadap pertambahan tinggi bibit Jati Belanda pada tanah Podsolik Merah Kuning. Untuk mengetahui perlakuan yang terbaik dalam mempengaruhi pertambahan tinggi bibit Jati Belanda, maka dilakukan pengujian terhadap rerata perbedaan masing-masing perlakuan dengan menggunakan Uji Beda Nyata Terkecil (BNT) pada taraf nyata $5 \%$ dan $1 \%$.

Tabel 4. Uji Beda Nyata Terkecil Pengaruh Pemberian Pupuk NPK Mutiara Terhadap Pertambahan Tinggi Bibit Jati Belanda Pada Tanah Podsolik Merah Kuning

\begin{tabular}{|c|c|c|c|c|c|c|c|}
\hline \multirow{2}{*}{ Perlakuan } & \multirow{2}{*}{ Rerata } & \multicolumn{7}{|c|}{ Beda } \\
\cline { 3 - 8 } & & N0 & N1 & N2 & N3 & N4 & N5 \\
\hline N0 & $\mathbf{2 4 , 7 5}$ & & & & & & \\
\hline N1 & $\mathbf{3 0 , 7 5}$ & $6,00^{* *}$ & & & & & \\
\hline N2 & $\mathbf{3 1 , 7 5}$ & $7,00^{* *}$ & $1,00^{* *}$ & & & & \\
\hline N3 & $\mathbf{3 2 , 2 5}$ & $7,50^{* *}$ & $1,50^{* *}$ & $0,50^{\text {ns }}$ & & & \\
\hline N4 & $\mathbf{3 3 , 5 0}$ & $8,75^{* *}$ & $2,75^{* *}$ & $1,75^{* *}$ & $1,25^{* *}$ & & \\
\hline N5 & $\mathbf{3 3 , 5 0}$ & $8,75^{* *}$ & $2,75^{* *}$ & $1,75^{* *}$ & $1,25^{* *}$ & $0,00^{\text {ns }}$ & \\
\hline \multicolumn{7}{|c|}{ BNT 5\% : $\mathbf{0 , 5 3}$ BNT 1\% : 0,72 } \\
\hline
\end{tabular}

Sumber : Analisis Data Penelitian, 2017.

Keterangan : $* *=$ Berbeda sangat signifikan

$\mathrm{ns}=$ Tidak berbeda signifikan 
Hasil Uji BNT perbedaan masingmasing perlakuan pupuk NPK Mutiara terhadap pertambahan tinggi bibit Jati Belanda pada tanah Podsolik Merah Kuning diketahui bahwa pemberian pupuk NPK Mutiara dengan dosis 6 gram per bibit (N4) dan 7 gram per bibit (N5), merupakan perlakuan terbaik untuk meningkatkan pertambahan tinggi bibit Jati Belanda. Hal ini terlihat dengan jelas bahwa N5 dan N4 tidak berbeda (menghasilkan pertambahan tinggi bibit yang sama), dan kedua perlakuan tersebut berbeda sangat signifikan dibandingkan dengan perlakuan lain N3 (pupuk NPK Mutiara 5 gram per bibit), dengan N2 (pupuk NPK Mutiara 4 gram per bibit), N1(pupuk NPK Mutiara 3 gram per bibit) dan dengan N0 (tanpa pupuk NPK Mutiara).

\section{Pembahasan}

\section{Pertambahan Jumlah Daun Bibit Jati}

\section{Belanda}

Berdasarkan hasil analisis sidik ragam sebagaimana tabel 4.2 diketahui bahwa pemberian pupuk NPK Mutiara memberikan pengaruh sangat signifikan terhadap pertambahan jumlah daun bibit Jati Belanda pada tanah Podsolik Merah Kuning. Selanjutnya berdasarkan uji
BNT pada tabel 4.3. diketahui bahwa pemberian pupuk NPK Mutiara dengan dosis 6 gram per bibit (N4) dan dosis 7 gram per bibit (N5), adalah perlakuan yang terbaik untuk meningkatkan pertambahan jumlah daun bibit Jati Belanda dibandingkan dengan perlakuan lainnya, dengan rerata pertambahan jumlah daun sebanyak 16,75 helai.

Hasil penelitian ini, menunjukkan bahwa pemberian pupuk sangat memegang peranan penting bagi pertumbuhan dan perkembangan suatu tanaman. Konsentrasi yang terlalu rendah akan mengakibatkan pertumbuhan (dalam hal ini adalah pertambahan jumlah daun) menjadi lama, sedangkan konsentrasi yang terlalu tinggi akan berakibat racun bagi bibit tanaman, sehingga pertumbuhan dan perkembangannnya menjadi terhambat dan tumbuhan akan tumbuh secara maksimal bila dosis pupuk yang diberikan seimbang (sesuai dengan kebutuhannya).

\section{Pertambahan Tinggi Bibit Jati Belanda}

Berdasarkan hasil analisis sidik ragam sebagaimana tabel 4.5 diketahui bahwa pemberian pupuk NPK Mutiara 
memberikan pengaruh sangat signifikan terhadap pertambahan tinggi bibit Jati Belanda pada tanah Podsolik Merah Kuning selama kurun waktu penelitian. Selanjutnya berdasarkan uji BNT sebagaimana tabel 4.6. diketahui bahwa pemberian pupuk NPK Mutiara dengan dosis 6 gram per bibit (N4) dan 7 gram per bibit (N5), adalah perlakuan yang terbaik untuk meningkatkan pertambahan tinggi bibit Jati Belanda dibandingkan dengan perlakuan lainnya, dengan rerata pertambahan tinggi $33,50 \mathrm{~cm}$. Hal ini mengindikasikan bahwa pemberian pupuk NPK Mutiara dengan dosis tersebut adalah yang terbaik sekaligus paling tepat, karena pada perlakuan tersebut telah terjadi pertumbuhan yang maksimal.

Pemberian pupuk yang mengandung $\mathrm{N}, \mathrm{P}$, dan $\mathrm{K}$ sangat berguna untuk menambah tinggi tanaman. Pemberian unsur $\mathrm{N}$ pada tahap perkembangan tanaman akan merangsang pertumbuhan dan pertambahan tinggi tanaman, sedangkan adanya unsur $\mathrm{K}$ merupakan sebagai pengimbang pengaruh $\mathrm{N}$ dan $\mathrm{P}$ serta meransang pertumbuhan akar. Hal ini ditegaskan oleh Harjadi (1996:21) bahwa bertambah tingginya tanaman disebabkan oleh terjadinya pembelahan dan perpanjangan sel pada daerah meristem ujung tunas dan ujung akar.

Ketersedian unsur hara sangat mempengaruhi laju pertumbuhan suatu tanaman. Suatu kondisi yang sangat penting bagi pertumbuhan dan kesehatan tanaman adalah persediaan jumlah unsur hara yang sesuai, memadai dan seimbang secara tepat waktu yang bisa diserap langsung oleh tanaman. Kekurangan dan ketidakseimbangan unsur hara merupakan halangan utama bagi pertumbuhan tanaman. Ketersediaan unsur hara sangat tergantung pada kodisi umum tanah, kehidupan tanah dan pengolahan bahan organik. Oleh karena itu, untuk mendapatkan pertumbuhan yang maksimum mutlak diberikan unsur hara pada taraf optimum bagi tanaman tersebut. Hal tersebut dipertegas oleh Harjadi (1996:23), yang menyatakan bahwa kurang tersedianya unsur hara dapat mengakibatkan terhambatnya proses metabolisme dalam tubuh tanaman, keadaan ini pada akhirnya akan menghambat pembentukan akar, batang dan daun. Pertumbuhan dan perkembangan daun sangat dipengaruhi oleh akar tanaman. Apabila 
pertumbuhan akar terhambat maka akan menghambat pertumbuhan tanaman pada bagian atasnya. Terhambatnya pertumbuhan akar mengakibatkan terhambatnya pertumbuhan organ tanaman lainnya.

\section{PENUTUP}

\section{Kesimpulan}

Berdasarkan hasil penelitian dan pengamatan, maka dapat disimpulkan sebagai berikut;

1. Pemberian pupuk NPK Mutiara berpengaruh sangat signifikan terhadap pertambahan jumlah daun dan tinggi bibit Jati Belanda pada tanah Podsolik Merah Kuning.

2. Perlakuan pemberian pupuk NPK Mutiara dengan dosis dosis 6 gram per bibit (N4) dan 7 gram per bibit (N5) adalah yang terbaik dibandingkan dengan perlakuan lainnya, yang mampu memacu rerata pertambahan jumlah daun sebanyak 16,75 (helai) dan rerata pertambahan tinggi bibit Jati Belanda sebanyak $33,50 \mathrm{~cm}$.

\section{Saran}

Apabila faktor ekonomis yang menjadi dasar pertimbangan, untuk upaya budidaya dalam skala yang besar, maka pemberian pupuk NPK Mutiara dengan dosis sebanyak 6 gram per bibit (N4) adalah yang dianggap paling baik dan dapat dijadikan sebagai acuan dalam upaya budidaya tanaman Jati Belanda.

\section{DAFTAR PUSTAKA}

Ahmad Yamani, Sulaiman Bakri, Asmuri Achmad, dan Normela Rachmawati. 2013. Pengaruh Pupuk NPK Mutiara Terhadap Pertumbuhan Anakan Tanaman Tanjung (Mimusops Elengi L) Di Seed House Fakultas Kehutanan Unlam Banjarbaru. Jurnal Riset Kehutanan.

Buckman, H.O, dan Brady, N.C. 1982. Ilmu Tanah. Diterjemahkan oleh Soegiman. Jakarta: Bharata Karya Aksara.

Hanafiah, KA. 2008. Rancangan Percobaan. Jakarta : PT. Raja Grafindo Persada.

Jaka Sulaksana dan Dadang Iskandar Jayusman. 2005. Kemuning dan Jati Belanda. Jakarta. Penebar Swadaya.

Lingga, P. 1991. Petunjuk Penggunaan Pupuk. Jakarta. Penebar Swadaya.

Salisbury dan Ros. 1992. Fungsi Unsur Hara Makro dan Mikro. Jakarta: PT. Foreverindo Insan Abadi

Sarief, S. 1986. Kesuburan dan Pemupukan Tanah Pertanian. Bandung: Pustaka Buana.

Setyamidjaya, D. 1986. Pupuk dan Pemupukan, Jakarta: Simplex 
